\title{
New records of Pouteria macrocarpa (Sapotaceae) from the Brazilian Atlantic forest
}

\author{
Arnaldo Zanetti Mônico ${ }^{1}$, Lucas de Almeida Silva ${ }^{1,2}$, Valquíria Ferreira Dutra ${ }^{1,2}$, Joelcio Freitas ${ }^{1}$ \\ \& Anderson Alves-Araújo ${ }^{1,3}$
}

\begin{abstract}
We present the first voucher-based record of Pouteria macrocarpa for Brazilian Atlantic forest and extend the occurrence area of it. Besides, a brief taxonomic description, an identification key for lignified-fruits Pouteria species, and information about phenology and herbarium records are provided. According to the IUCN Red List and the Red Book of the Brazilian Flora, the species is considered Vulnerable (VU). However, facing the new available data, we believe it should be reassessed as Endangered (EN).

Key words: Brazil, Chrysophylloideae, Ericales, Espírito Santo, Neotropics.

\section{Resumo}

Este é primeiro registro baseado em vouchers de Pouteria macrocarpa para a Mata Atlântica e informações sobre novas áreas de ocorrência da espécie são disponibilizadas. Além disso, são apresentadas uma breve descrição taxonômica, uma chave de identificação de espécies morfologicamente afins e informações fenológicas e das coleções botânicas. De acordo com a Lista Vermelha da IUCN e do Livro Vermelho da Flora Brasileira, a espécie é considerada Vulnerável (VU), no entanto, após re-análise dos dados aqui apresentados, $P$. macrocarpa deve ser recategorizada como Em Perigo (EN).

Palavras-chave: Brasil, Chrysophylloideae, Ericales, Espírito Santo, Neotrópicos.
\end{abstract}

Atlantic Forest Domain encompasses about 16,000 plant species in a mixture of contrasting vegetation types, which around $45 \%$ of them are considered endemic (Stehmann et al. 2009). It corresponds to $5 \%$ of the global number of species making it as one of the top five world biodiversity hotspots for angiosperms (Mittermeier et al. 2005). Facing the importance of knowing its biodiversity, the Atlantic Forest is the second main distribution center in South America for the latescent family Sapotaceae which is often cited in floristic studies (Peixoto \& Gentry 1990; Fabris \& César 1996; Thomaz \& Monteiro 1997; Saiter et al. 2011). However, those lists usually show high levels of non-specific determination.
Pouteria Aubl.(Sapotaceae, Chrysophylloideae) is the largest genus in the family and includes ca. 200 species (Anderberg \& Swenson 2003; Bartish et al. 2005; Swenson \& Anderberg 2005; Swenson et al. 2007, 2008). The genus is restricted to the Neotropics (Swenson et al. 2013) and in Brazil, of 122 registered species, 50 are considered endemic (BFG 2015).

Pouteria shows a great morphological variability but is characterized predominantly by arboreal individuals; absence of stipules; flowers with 4-6 free, imbricate sepals; tubular-cyathiform corolla with six lobes; stamens opposite to the corolla lobes, staminodes alternate to the corolla lobes; ovary 1-6(-15)-locular and seeds with presence of adaxial scar, with or without endosperm (Pennington 1991).

\footnotetext{
'Universidade Federal do Espírito Santo - UFES, CEUNES/DCAB, Prog. Pós-graduação em Biodiversidade Tropical - PPGBT, Lab. Sistemática e Genética Vegetal - SGV, Rod. BR-101 Norte, Km 60, Bairro Litorâneo, 29932-540, São Mateus, ES, Brasil.

${ }^{2}$ Universidade Federal do Espírito Santo - UFES, CCHN/DCBIO, Lab. Taxonomia Vegetal, Av. Fernando Ferrari 514, Bairro Goiabeiras, Vitória, ES, Brasil.

${ }^{3}$ Author for correspondence: sapotae@gmail.com
} 
Indeed, while carrying out a taxonomic survey of Pouteria in the Estação Biológica Santa Lúcia Biological (EBSL), a non-official protected area in the Espírito Santo State, Brazil. Fieldwork was performed from September/2013 to July/2014 and a novelty for Atlantic Forest was recognized: Pouteria macrocarpa (Mart.) Dietr.

Main herbaria with holdings of Sapotaceae, especially from Espírito Santo State, were visited and/or consulted (CEPEC, CVRD, F, MBML, MO, NY, RB, VIES) (acronyms according to Thiers, continuously updated). For identification, type specimens, herbarium vouchers, and literature data were consulted and analyzed (Pennington 1990, 1991, 2006). For taxonomic description only specimens from Atlantic forest were considered.

The conservation status follow the IUCN red list criteria for assessments (IUCN 2014). Extent of Occurrence (EOO) and Area of Occupancy (AOO) were calculated using GeoCat - Geospatial Conservation Assessment Tool (Bachman et al. 2011) for assessments of extinction risk. Herein, only specimens determined by Sapotaceae specialists were considered.
Pouteria macrocarpa (Mart.) Dietr., Syn. pl., 1: 431. 1839. -non Pouteria macrocarpa (Huber) Ducke [=Pouteria multiflora (A.DC.) Eyma].

Figs. 1; 2

Pouteria macrocarpa is a tree species up to $20 \mathrm{~m}$ tall with large lignified globoid fruits $(3.5-4.6 \times 4.8-6.3 \mathrm{~cm})$, scaling bark, and squamous branches; eucamptodromous leaves arranged in the apical portion of the branch, long petioles (3.2-4.5 $\mathrm{cm}$ ) and straight secondary veins, often with no inter-secondary, and tertiary oblique.

Specimens examined: BRAZIL. BAHIA: Arataca, PARNA de Serra das Lontras, Trilha do mirante de Seu Artur, fr., 12.IX.2011, R.O. Perdiz et al. 940 (CEPEC, RB). ESPÍRITO SANTO: Santa Teresa, São Lourenço, Mata Fria, fr., 27.I.1999, L. Kollmann 1710 (MBML); Cabeceira do Rio Bonito, fr., 13.VI.2001, L. Kollmann 3961 (MBML); Estação Biológica de Santa Lúcia, fr., 5.IX.2001, L. Kollmann 4512 (MBML); fr., 18.IX.2002, R.R. Vervloet 913 (MBML); Nova Lombardia, Reserva Biológica (Rebio) Augusto Ruschi, fr., 1.IX.2002, R.R. Vervloet 620 (MBML).

Pouteria macrocarpa is easily recognized from the remaining lignified-fruit Pouteria species by puberulous and shorter pedicels $(1.3-2.2 \mathrm{~cm})$, and eucamptodromous leaves (see key below) (Fig. 1).

\section{Key to lignified-fruit Pouteria species morphologically similar to Pouteria macrocarpa}

1. Pedicels glabrous.

2. Leaves elliptic or elliptic-oblong, secondary veins parallel, straight to slightly arcuate, intersecondary rare, tertiary inconspicuous; pedicels $2-3 \mathrm{~mm}$; seeds- 1 ................ Pouteria foveolata

2'. Leaves oblanceolate, secondary veins slightly convergent, arcuate, inter-secondary short to moderately long, tertiary open-reticulated; pedicels $0.9-1.2 \mathrm{~mm}$; seeds-several

Pouteria laevigata

1'. Pedicels puberulous.

3. Leaves eucampto-broquidodromous, marginal veins obscure or absent, petioles length (2.2-)3-4.5 $\mathrm{cm}$; pedicels $0.8-2.1 \mathrm{~mm}$; seeds one-several...... Pouteria lucuma

3'. Leaves eucamptodromous, thin marginal veins present, petioles length $1.3-2.2 \mathrm{~cm}$; pedicels $1-1.5$ $\mathrm{mm}$; seeds-several.

Pouteria macrocarpa

The species has a known geographic distribution in Central and South America, from Costa Rica, Colombia (1,800 m alt.) to Brazilian Amazonian forest (Pennington 1991), and despite its geographic distribution, the species is apparently rare. Carneiro et al. (2013) barely cited it as occurring in the Atlantic forest when they give status of conservation assessments for several Brazilian plant species. However, this latter work did not mention which specimens were examined or any literature information they followed to ensure the real identity of the vouchers.

According to BFG (2015), P. macrocarpa is recorded to the Brazilian states of Amazonas, Pará, and Roraima. Thus, this is the first voucher-based record from the Brazilian Atlantic forest in the Bahia and Espírito Santo states to P. macrocarpa which now bears a disjunct distribution between Amazonian and Atlantic forests (Fig. 2). It endorses the list of Pouteria species cited by 

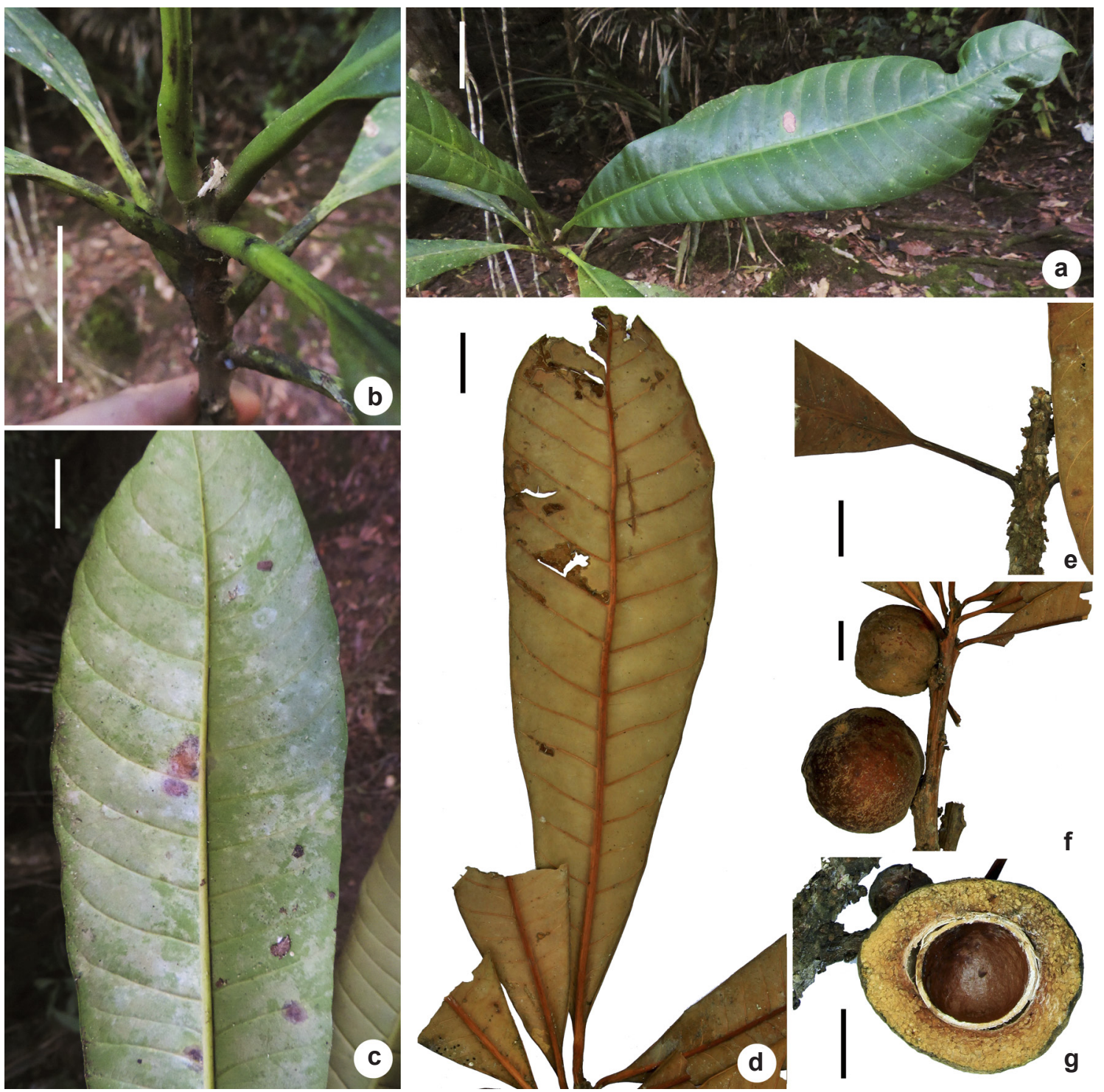

Figure 1 - Pouteria macrocarpa - a. leaves; b. petioles; c-d. venation pattern on living and dried samples; e. petiole and buds; f. fruits; g. fruit and seed. [a-c. Mônico, A. (MBML); d-g Vervloet, R. 913 (MBML)]. Scale bar $=2 \mathrm{~cm}$.

Alves-Araújo et al. (2014) and other groups of plants (Alves et al. 2003; Marchioretto et al. 2004; Melo et al. 2009; Pontes \& Alves 2011). Additionally, the species is often associated to the lowland forests, with only one record from Colombian mountains.

The new populations are represented by five fertile records from Espírito Santo (four subpopulations) and Bahia states at MBML, CEPEC and RB herbaria (Tab. 1). There is one more specimen from Minas Gerais state at $\mathrm{F}$ herbarium which represents a historical record collected in 1930 (Pennington 1990) (Tab.1). However, the latter has no precise location and therefore was not included during threat assessments.

Pouteria macrocarpa shows an EOO of $5,166,542.196 \mathrm{~km}^{2}$ and considering a discontinuous area between the Amazonian and Atlantic forests, the species would fit Least Concern (LC) assessment. In addition, the Red Book of Brazilian Flora (Carneiro et al. 2013) and the IUCN Red List 


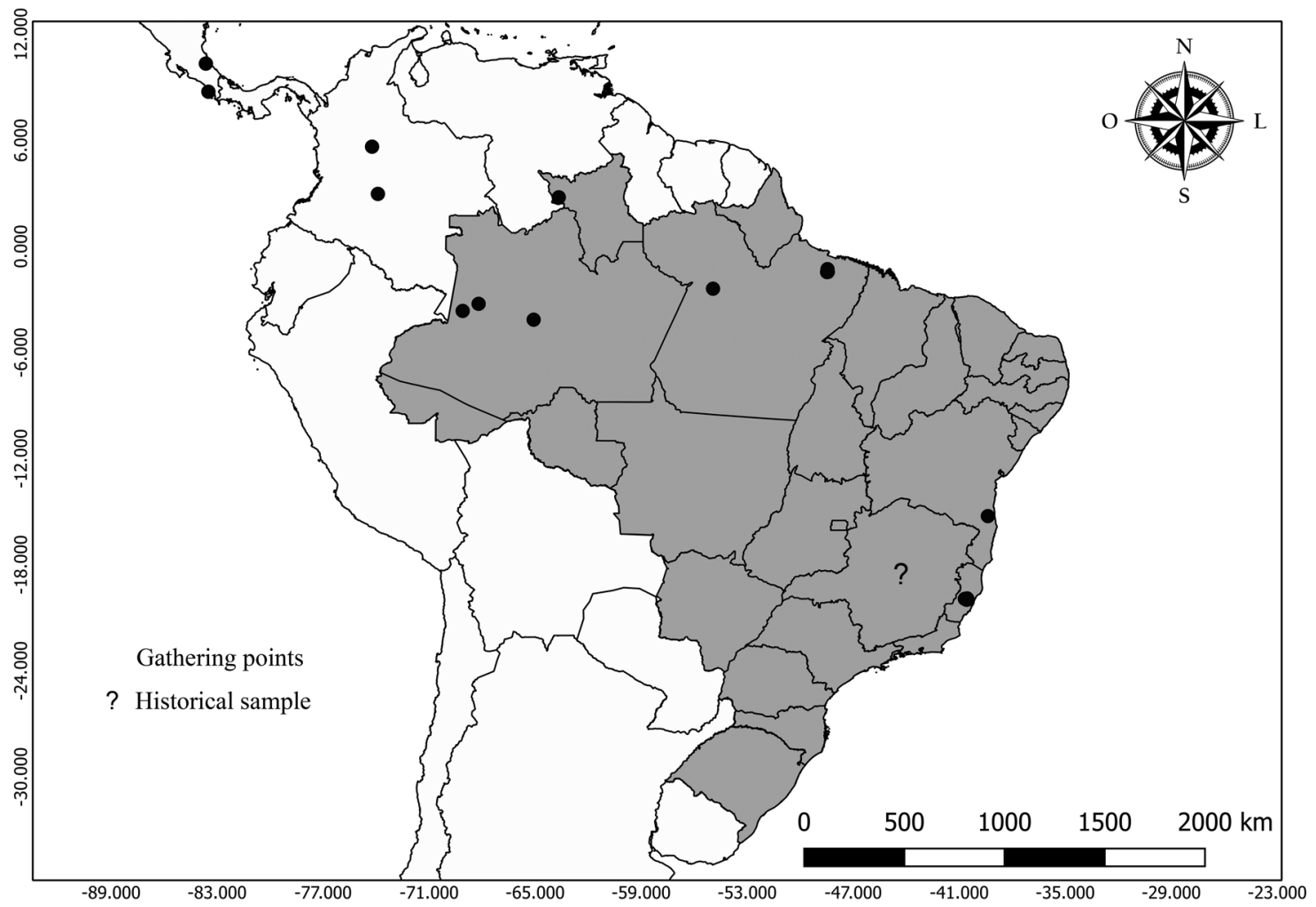

Figure 2 - New records of Pouteria macrocarpa (Mart.) Dietr. - (•) historical record with no precise location.

(IUCN 2015), assessed the species as Vulnerable. However, including the newly known records and with an AOO displaying a total of $68,000 \mathrm{~km}^{2}$, the species should be, actually, considered as Endangered (EN), according to criteria B2b(iii) and C1 (IUCN 2012, 2013, 2014).

Three out of six specimens from Atlantic forest were mentioned as occurring in the EBSL.
Plant taxonomy researches have been carried out on EBSL and have shown taxonomic novelties (Baitello 2001; Mass et al. 2001; Lombardi 2004; Fiaschi \& Pirani 2005; Fraga \& Saavedra 2006; Goldenberg \& Reginato 2006; Alves-Araújo \& Mônico 2017).

ESBL is part of one of the most important refuges for Brazilian flora in the Atlantic forest

Table 1 - Details of the new records of the tree species Pouteria macrocarpa in southeastern Brazil - (*) Historical record with no precise location.

\begin{tabular}{|c|c|c|c|c|}
\hline State/City & Locality & Year & Collector (Herbarium) & Phenology \\
\hline Minas Gerais* & Districto Ilheu, Fazenda de Tabunha & $1930 *$ & Mexia, Y. $4995(F)$ & Fruit \\
\hline Espírito Santo/Santa Teresa & São Lourenço, Mata Fria & 1999 & Kollmann, L. 1710 (MBML) & Fruit \\
\hline Espírito Santo/Santa Teresa & Cabeceira do Rio Bonito & 2001 & Kollmann, L. 3961 (MBML) & Fruit \\
\hline Espírito Santo/Santa Teresa & Estação Biológica de Santa Lúcia & 2001 & Kollmann, L. 4512 (MBML) & Fruit \\
\hline Espírito Santo/Santa Teresa & Estação Biológica de Santa Lúcia & 2002 & Vervloet, R. 913 (MBML) & Fruit \\
\hline Espírito Santo/Santa Teresa & Nova Lombardia, Rebio Augusto Ruschi & 2002 & Vervloet, R. 620 (MBML) & Fruit \\
\hline Bahia/Arataca & Parque Nacional de Serra das Lontras & 2011 & Perdiz, R. 940 (RB) & Fruit \\
\hline Espírito Santo/Santa Teresa & Estação Biológica de Santa Lúcia & 2014 & Mônico, A. s.n. (MBML) & Sterile \\
\hline
\end{tabular}


which constitute a green aisle where there are no high levels of logging. However, this scenario is different for Amazonian populations of $P$. macrocarpa due to the species domestication and its commercially valuable wood which might lead to genetic variability decrease (Carneiro et al. 2013).

\section{Acknowledgments}

We thank the staff members from Museu de Biologia Mello Leitão (Instituto Nacional da Mata Atlântica) for all the assistance, especially Helio de Queiroz Boudet Fernandes, MBML curator; AZM, LAS and JF thank CAPES - Coordenação de Aperfeiçoamento de Pessoal de Nível Superior for the fellowship granted; and AAA thanks FAPES - Fundação de Amparo à Pesquisa e Inovação do Espírito Santo, Termo de Outorga 0744/2015 for funding this project.

\section{References}

Alves MV, Thomas WW \& Wanderley MGL (2003) Padrões de distribuição geográfica das espécies neotropicais de Hypolytrum Rich. (Cyperaceae). Boletim de Botânica da Universidade de São Paulo 21: 265-276.

Alves-Araújo A \& Mônico AZ (2017) Pouteria samborae, a new species of Sapotaceae (Chrysophylloideae) from Espírito Santo, Brazil. Systematic Botany 42: 358-363.

Alves-Araújo A, Swenson U \& Alves M (2014) A taxonomic survey of Pouteria (Sapotaceae) from the northern portion of the Atlantic Rainforest of Brazil. Systematic Botany 39: 915-938.

Anderberg AA \& Swenson U (2003) Evolutionary lineages in Sapotaceae (Ericales): a cladistic analysis based on ndhF sequence data. International Journal of Plant Sciences 164: 763-773.

Bachman S, Moat J, Hill AW, de la Torre J \& Scott B (2011) Supporting Red List threat assessments with GeoCAT: geospatial conservation assessment tool. In: Smith V \& Penev L (eds.) e-Infrastructures for data publishing in biodiversity science. ZooKeys 150: 117-126.

Baitello JB (2001) Novas espécies de Lauraceae para a flora brasileira. Acta Botanica Brasilica 15: 445-450.

Bartish IV, Swenson U, Munzinger J \& Anderberg AA (2005) Phylogenetic relationships among New Caledonian Sapotaceae (Ericales): molecular evidence for generic polyphyly and repeated dispersal. American Journal of Botany 92: 667-673.

BFG - The Brazil Flora Group (2015) Growing knowledge: an overview of seed plant diversity in Brazil. Rodriguésia 66: 1085-1113.
Carneiro CE, Kutschenko DC, Valente ASM, Barros FSM, Messina T \& Moraes MA (2013) Sapotaceae. In: Martinelli G \& Moraes MA(eds.) Livro vermelho da flora do Brasil. Instituto de Pesquisas Jardim Botânico do Rio de Janeiro, Rio de Janeiro. Pp. 956-967.

Fabris LC \& César O (1996) Estudos florísticos em uma mata litorânea no sul do estado do Espírito Santo, Brasil. Boletim do Museu de Biologia Mello Leitão (nova série) 5: 15-46.

Fiaschi P \& Pirani JR (2005) Four new species of Schefflera (Araliaceae) from Espírito Santo state, Brazil. Kew Bulletin 60: 77-85.

Fraga CN \& Saavedra MM (2006) Three new species of Elvasia (Ochnaceae) from the Brazilian Atlantic Forest with an emended key for subgenus Hostmannia. Novon 16: 473-479.

Goldenberg R \& Reginato M (2006) Sinopse da família Melastomataceae na Estação Biológica de Santa Lúcia (Santa Teresa, Espírito Santo). Boletim do Museu de Biologia Prof. Mello Leitão (Nova Série) 20: 33-58.

IUCN - International Union for Conservation of Nature (2012) Guidelines for application of IUCN Red List criteria at regional and national levels: version 4.0. IUCN, Gland and Cambridge. 41p.

IUCN - International Union for Conservation of Nature (2013) Documentation standards and consistency checks for IUCN Red List assessments and species accounts, ver. 2. Adopted by the IUCN Red List Committee and IUCN SSC Steering Committee. Available at $<$ http://www.iucnredlist.org/documents/ RL_Standards_Consistency.pdf $>$. Access on 4 June 2016.

IUCN - International Union for Conservation of Nature (2014) Guidelines for using the IUCN Red List Categories and Criteria, ver. 11. Available at $<\mathrm{http} / /$ www.iucnredlist.org/documents/RedListGuidelines. pdf $>$. Access on 4 Jun 2016.

IUCN - International Union for Conservation of Nature (2015) IUCN Red List of threatened species, ver. 2015.2. Available at $<\mathrm{http}: / / w w w . i u c n r e d l i s t . o r g>$. Access on 4 June 2016.

Lombardi JA (2004) Three new species of Celastraceae (Hippocrateoideae) from Southeastern Brazil, and a new combination in Peritassa. Novon 14: 315-321.

Marchioretto MS, Windisch PG \& Siqueira JC (2004) Padrões de distribuição geográfica das espécies de Froelichia Moench e Froelichiella R.E. Fries (Amaranthaceae) no Brasil. Iheringia Série Botânica 59: 149-159.

Mass P, Maas-Van Der Kamer H, Junikka L, Mello-Silva R \& Riner H (2001) Annonnaceae from Central-Eastern Brazil. Rodriguésia 52: 65-98.

Melo IM, Alves M \& Semir J (2009) Padrões de distribuição geográfica das espécies de Euploca e Heliotropium (Heliotropiaceae) no Brasil. Rodriguésia 60: 1025-1036. 
Mittermeier RA, Gil PR, Hoffman M, Pilgrim J, Brooks T, Mittermeier CG, Lamourex J \& Fonseca GAB (2005) Hotspots revisited: Earth's biologically richest and most endangered terrestrial ecoregions. CEMEX/Agrupación Sierra Madre, Mexico City. $342 p$.

Peixoto AL \& Gentry A(1990) Diversidade e composição florística da mata de tabuleiro na Reserva Florestal de Linhares (Espírito Santo, Brasil). Revista Brasileira de Botânica 13: 19-25.

Pennington TD (1990) Sapotaceae. Flora Neotropica. Monograph 52. The New York Botanical Garden, New York. 770p.

Pennington TD (1991) The genera of the Sapotaceae. Royal Botanic Gardens, Kew. 295p.

Pennington TD (2006) Flora da Reserva Ducke, Amazonas, Brasil: Sapotaceae. Rodriguésia 57: 251-366.

Pontes TA \& Alves M (2011) Padrões de distribuição geográfica das espécies de Araceae ocorrentes em fragmentos de floresta atlântica em Pernambuco, Brasil. Revista Brasileira de Biociências 9: 444-454.

Saiter FZ, Guilherme FAG, Thomaz LD \& Wendt T (2011) Tree changes in a mature rainforest with high diversity and endemism on the Brazilian coast. Biodiversity and Conservation 20: 1921-1949.

Stehmann JR, Forzza RC, Salino A, Sobral M, Costa DP \& Kamino LHY (2009) Diversidade taxonômica na Floresta Atlântica. In: Stehmann JR, Forzza RC, Salino A, Sobral M, Costa DP \& Kamino LHY (eds.) Plantas da floresta atlântica. Instituto de Pesquisas Jardim Botânico do Rio de Janeiro, Rio de Janeiro. Pp. 3-12.

Swenson U \& Anderberg AA (2005) Phylogeny, character evolution, and classification of Sapotaceae (Ericales). Cladistics 21: 101-130.

Swenson U, Bartish IV \& Munzinger J (2007) Phylogeny, diagnostic characters, and generic limitation of Australasian Chrysophylloideae (Sapotaceae, Ericales): evidence from ITS sequence data and morphology. Cladistics 23: 201-228.

Swenson U, Richardson JE \& Bartish IV (2008) Multigene phylogeny of the pantropical subfamily Chrysophylloideae (Sapotaceae): evidence of generic polyphyly and extensive morphological homoplasy. Cladistics 24: 1006-1031.

Swenson U, Nylinder S \& Munzinger J (2013) Towards a natural classification of Sapotaceae subfamily Chrysophylloideae in Oceania and Southeast Asia based on nuclear sequence data. Taxon 62: 746-770.

Thiers B [continuously updated]. Index Herbariorum: a global directory of public herbaria and associated staff. New York Botanical Garden's Virtual Herbarium. Available at <http://sweetgum.nybg. org/ih/>. Access on 4 June 2016.

Thomaz LD \& Monteiro R (1997) Composição florística da Mata Atlântica de encosta da Estação Biológica de Santa Lúcia, município de Santa Teresa - ES. Boletim do Museu de Biologia Prof. Mello Leitão (Nova Série) 7: 3-48. 